\begin{tabular}{|c|c|c|c|c|}
\hline Internat. Rev. Hydrobiol. & 86 & 2001 & $4-5$ & $527-540$ \\
\hline
\end{tabular}

\author{
Ana Sampaio ${ }^{1}$, Rui Cortes $^{2}$ and Cecília Leão 3 \\ ${ }^{1}$ Secção de Eng ${ }^{\text {a }}$ Biológica e Ambiental, Universidade de Trás-os Montes e Alto Douro, \\ Apartado 202, 5001 Vila Real Codex, Portugal \\ ${ }^{2}$ Departamento Florestal, Universidade de Trás-os Montes e Alto Douro, apartado 202, \\ 5001 Vila Real Codex, Portugal \\ ${ }^{3}$ Departamento de Biologia, Universidade do Minho, Gualtar, 4700 Braga, Portugal
}

\title{
Invertebrate and Microbial Colonisation in Native and Exotic Leaf Litter Species in a Mountain Stream
}

key words: decomposition, microbial content, invertebrates, litter

\begin{abstract}
Decomposition of three leaf species (Alnus glutinosa, Eucalyptus globulus and Quercus robur) were examined in a headstream. During two months decomposing leaves were periodically analysed for nutrient content, soluble sugars, phenols, protein precipitation capacity, total fiber, weight loss, microbial and macroinvertebrate colonisation. The leaves of the three species showed similar patterns in dynamics of soluble sugars, tannins and phenols. Bacteria numbers per foliar dry mass were constant in oak during the experiment, but increased linearly in eucalyptus. Total heterotrophic colony forming units (bacteria and fungi) were similar in eucalyptus and oak and constant during incubation, whereas in alder, they became more abundant. The analysis of invertebrate assemblages revealed differences between alder and the other two species related to nitrogen and microbial abundance.
\end{abstract}

\section{Introduction}

Terrestrial leaf litter constitutes a significant fraction of coarse particulate organic matter in low order streams. These systems have a high energy dependence on the organic matter supplied directly to the stream in the catchment area (MinsHALL, 1967). The decomposition rate of these inputs varies due to abiotic factors such as temperature, flow, physical fragmentation (PETERSEN and CUMMINS, 1974), pH (CHAMIER, 1987), water chemistry especially nitrate and phosphate concentrations (Pozo, 1993), initial litter quality (MeliLlo et al., 1984) and biotic factors such as invertebrate activities by direct feeding or fragmentation and microorganism colonisation (ANDERSON and SEDELL, 1979). These aspects have already been well documented. Changes in the catchment area such as pollution, clearcutting, fires and forest species replacement, can affect not only the total amount of litter, but also its quality with implications in all trophic levels (ABELHO and GRAÇA, 1996). Eucalyptus trees (Eucalyptus globulus, LABILL), were introduced into the Iberian Peninsula in 1829, and nowadays in Portugal eucalyptus monoculture is replacing deciduous and pine forests, occupying around $20 \%$ of the total forest area (CORTES et al., 1994). Eucalyptus leaves have a poor nutrient content in terms of nitrogen (Pozo, 1993) and are rich in polyphenols and condensed tannins. Their oils and a thick cuticle retard microbial attack and insect feeding (СANHOTO and GRAÇA, 1999). Furthermore, the input of eucalyptus leaves in the streams occurs mainly in summer when shredder density is relatively scarce. Moreover, there is a lack of studies in Iberian Peninsula comparing the relative importance of microbial colonisation groups in leaf breakdown. The purpose of this study was investigate the decay of three leaf litter species, two of them native in the Olo basin (alder and oak) and one exotic (eucalyptus), relatively widespread in 
Northern Portugal. The objectives included: (i) the documentation of the dynamics of several chemical parameters during leaf decomposition; (ii) test for differences in leaf-associated invertebrate communities; (iii) investigation of potential variation in microorganisms such as bacteria, total heterotrophic and yeasts during incubation; (iv) the determination of the main biotic and abiotic factors influencing invertebrate colonisation.

\section{Material and Methods}

\subsection{Study Area}

The study site is located in the Olo river basin, a second order stream. The water course length is $40 \mathrm{~km}$, with a catchment area of $143.8 \mathrm{~km}^{2}$ in an area of reduced human impact. The waters are acidic with a low concentration of inorganic substances. Yearly maximums for several chemical parameters of water quality in the study site were (CORTES et al., 1995): conductivity $39.6 \mu \mathrm{S} \cdot \mathrm{cm}^{-1}$, $\mathrm{N}-\mathrm{NO}^{3-} 0.6 \mathrm{mg} \cdot 1^{-1}, \mathrm{P}-\mathrm{PO}_{4}^{3-} 0.05 \mathrm{mg} \cdot 1^{-1}, \mathrm{Cl}^{-} 2.0 \mathrm{mg} \cdot \mathrm{l}^{-1}$ and $\mathrm{SO}_{4}^{2-} 2.1 \mathrm{mg} \cdot \mathrm{l}^{-1}$. The geological substratum is dominated by granites (headwaters) and by schist and quartzite in middle and lower reaches. The riparian vegetation is characterised by alder (Alnus glutinosa), willow (Salix atrocinea), ash (Fraxinus angustifolia) and oaks (Quercus pyrenaica and Q. robur). Intensive afforestations with pine (Pinus pinaster) and eucalyptus (E. globulus) are common in the lower reaches of this basin.

\subsection{Field and Laboratory Techniques}

Leaves of A. glutinosa, E. globulus and $Q$. robur were picked from the trees and collected from the middle of October to early November 1997, air dried at $40^{\circ}$ ( 48 hours) and stored until use. At the end of January 1998, the leaves were weighted into $4.0 \pm 0.1 \mathrm{~g}$ (alder and oak) and $6.0 \pm 0.1 \mathrm{~g}$ (eucalyptus), rehydrated and placed in a $5 \mathrm{~mm}$ mesh bag. The sealed bags were attached to nylon ropes and firmly anchored to the stream bed. After 1, 7, 14, 28 and 56 days of immersion (study limit imposed by bag losses), four bags of each leaf species were transported to the laboratory in a cooling box. The samples were treated as follow: (i) The contents of three bags were rinsed with tap water, the macroinvertebrates were retrieved and preserved in $70 \%$ ethanol until identification. The bags were oven dried at $40^{\circ}$ (48 hours) to obtain dry mass. The content of these bags were used for chemical analysis. (ii) One litter-bag (transported in a sterilised container) was used to determine microbial numbers.

Leaves used for determination were ground to pass through a $250 \mu \mathrm{m}$ sieve and the following chemical parameters were determined in each sample: total nitrogen, phosphorus, potassium, soluble sugars, polyphenols, tannins, and total fiber. These parameters were expressed in percentage of dry weight.

Total nitrogen was determined using the Kjeldahl method, phosphorus concentration in the ash was determined by the molybdovanate reaction according to MILLS and JONES, (1996) and potassium by spectrophotometric flame (NOVOZAMSKI et al., 1983).

Soluble sugars and total polyphenols were extracted with $50 \%$ methanol for 30 minutes at $80{ }^{\circ} \mathrm{C}$, a procedure repeated twice. The total extracts were used to estimate total polyphenols by Folin-Ciocalteau reagent using gallic acid as the standard (ROSSET et al., 1982) and soluble sugars measured colorimetrically by the anthrone method and D-glucose as the standard (AsHwell, 1957).

Total fiber (neutral detergent fiber - NDF) was estimated according to the ROBERTESON and VAN SOEST (1981) method, after solubilization, by a neutral solution of a tensioactive agent, of soluble carbohydrates, proteins, lipids and mineral substances. The residue was made up of hemicellulose, cellulose, lignin, cutin, insoluble mineral substances, a few structural proteins and silica.

The tannins were measured indirectly by the radial diffusion method. This method measures the protein precipitation capacity of tannins. The plant tissue was extracted for 1 hour, at room temperature, using $70 \%$ acetone as the solvent (HAGERMAN, 1987).

In order to quantify the microorganisms in the leaves, one litter bag was put in an Erlenmeyer with $100 \mathrm{ml}$ of sterilised $0.1 \%$ peptone water (w/v) and shaken at 100 r.p.m. for $30 \mathrm{~min}$. The samples were then sonicated for 3 minutes and vortexed. To determine the viable counts, bacteria, filamentous fungi and yeast were recovered by spreading aliquats of $100 \mu \mathrm{l}$ into plates of selective solid media, using the dilution plate-count technique. For each dilution three replicas were taken. Bacteria were cultured in solid Luria-Buria medium, yeast in Wort-lac agar (Wort medium acidified with lactic acid to $\mathrm{pH}$ 
3.0-3.5), and total heterotrophic microorganisms (bacteria and fungi including yeast cells) were determined by using the $\mathrm{R}_{2} \mathrm{~A}$ medium. The three media were purchased from DIFCO Laboratories (Detroit, USA). The inoculated plates were incubated at $23{ }^{\circ} \mathrm{C} \pm 2$ for 5 days, after which the CFUs per $\mathrm{ml}$ of undiluted peptone water were counted. The used leaves were oven dried to a constant weight, in order to express the results in CFUs/dry mass.

Invertebrates were observed under a binocular stereoscope and identified, where possible, to species level, except for Diptera and Oligochaeta, where identification extended only to the family or subfamily level.

\subsection{Statistical Analysis}

Decomposition rates were determined by fitting weight remaining dry mass by the negative exponential model (PETERSEN and CuMmins, 1974).

To determine statistical differences between leaf species and incubation periods, the microbial data were $\log (\mathrm{x}+1)$ transformed and the variance analysed with ANOVA. Macroinvertebrate data were also transformed $[\log (\mathrm{x}+1)]$, to reduce the effect of the most abundant taxa, while environmental data were linear transformed by standard deviation in order to account for the different scales and units of each variable (the standard deviation became 1.0 for each parameter). The samples of alder and oak from the $1^{\text {st }}$ day of incubation were eliminated as the macroinvertebrates were virtually absent.

Ordination procedures were used for data treatment, involving Detrended Correspondence Analysis (DCA) (HILl, 1979) and Canonical Correspondence Analysis (CCA) (TER BRAAK, 1987). DCA, only uses the species matrix, and it is a modification of the traditional Correspondence Analysis designed to correct for the lack of independence of the extracted axes and the compression at the ends of these axes. CCA, uses both matrices of species and environmental variables, selecting the linear combination of environmental variables that maximise the dispersion of species scores, and it is considered for this reason a method of direct gradient analysis. The software CANOCO, version 4.0 (TER BRAAK and SMILAUDER, 1998) performs both methods.

\section{Results}

\subsection{Organic Matter Losses and Decomposition Rates}

Alder leaves decomposed faster than oak or eucalyptus leaves. Exponential breakdown coefficients ranged from $-0.0135 \mathrm{~d}^{-1}$ (alder) to $-0.0083 \mathrm{~d}^{-1}$ (eucalyptus). In the first two weeks (14 days), alder leaves lost nearly $40 \%$ of initial dry weight while oak and eucalyptus leaves lost nearly $10 \%$ and $20 \%$, respectively (Fig. 1).

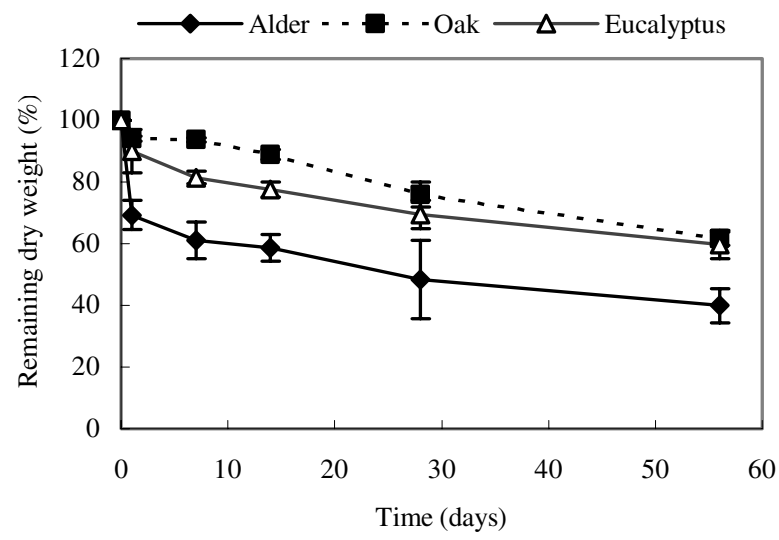

Figure 1. Dynamics of leaf mass loss in alder, oak and eucalyptus submerged leaves with time $($ mean $\pm \mathrm{SD}, \mathrm{n}=3$ ). 
Table 1. Chemical composition of alder, oak and eucalyptus leaves prior to stream incubation (day 0). Values are expressed in percentage of dry weight (mean $\pm S D, n=4$ ). For $\mathrm{N}, \mathrm{P}$ and $\mathrm{K}$ values $\mathrm{n}=2$. $\mathrm{PPC}=$ protein precipitation capacity.

\begin{tabular}{lccc}
\cline { 2 - 4 } Parameters & \multicolumn{3}{c}{ Day 0} \\
\cline { 2 - 4 } & Alder & Oak & Eucalyptus \\
\hline Total N & 3.00 & 0.71 & 0.99 \\
Total P & 0.16 & 0.05 & 0.09 \\
K & 0.80 & 0.08 & 0.36 \\
Soluble sugars & $11.20 \pm 1.55$ & $2.50 \pm 0.24$ & $3.10 \pm 0.07$ \\
Polyphenols & $7.90 \pm 0.27$ & $6.60 \pm 0.52$ & $8.90 \pm 0.20$ \\
PPC & $1.52 \pm 0.11$ & $3.12 \pm 0.30$ & $1.97 \pm 0.18$ \\
\hline
\end{tabular}

\subsection{Litter Quality}

The chemical composition of the litter before the experiment is shown in Table 1. Alder leaves were nutritionally richer (higher N, P and K contents) than eucalyptus and oak, and have a lower protein precipitation capacity.
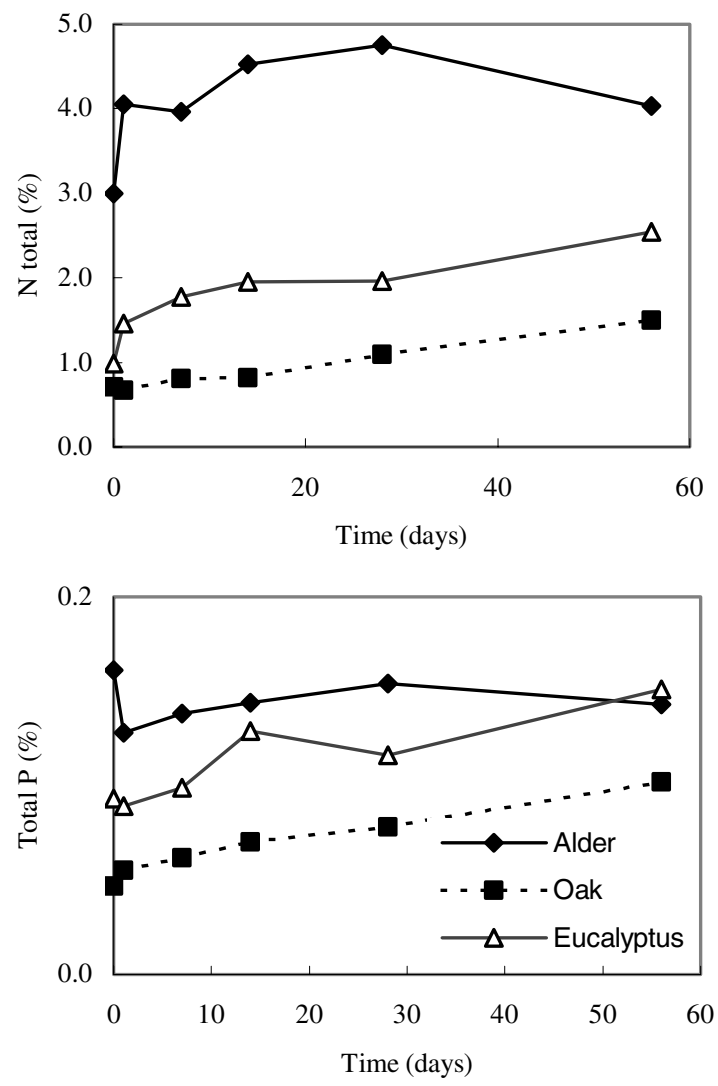

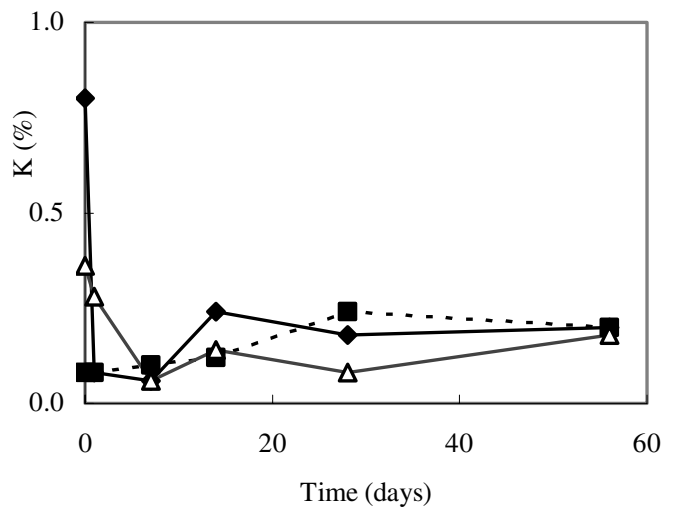

Figure 2. Temporal dynamics of N, P and $\mathrm{K}$ in alder, oak and eucalyptus leaves. Values are the mean of 2 replicates. 


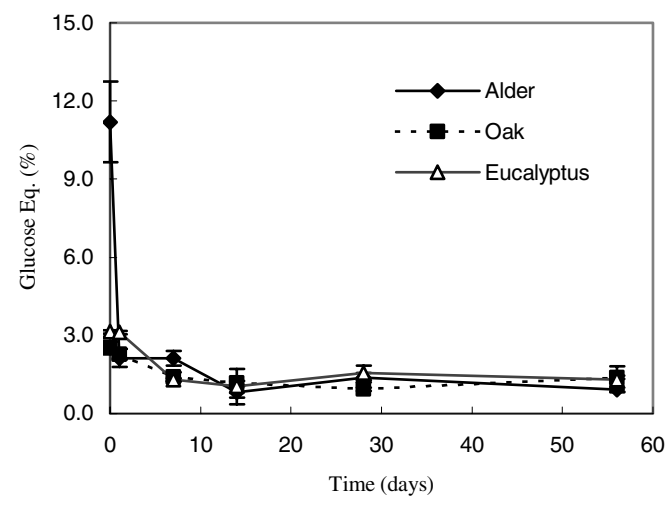

Figure 3. Temporal dynamics of soluble sugars, expressed in glucose equivalents, in alder, oak and eucalyptus leaves (mean $\pm \mathrm{SD}, \mathrm{n}=4$ ).

Fig. 2 shows the dynamics of the main nutrients in the submerged leaves during the study period. There was a general increase in $\mathrm{N}$ in the three leaf species. However, in alder, after day 28 , the $\mathrm{N}$ content began to decrease, suggesting a faster decomposition rate. The $\mathrm{P}$ concentration in eucalyptus and oak leaves showed a slight increase through time incubation period; in the alder leaves, the $\mathrm{P}$ concentration remained practically constant during the study period. The $\mathrm{K}$ content showed no visible variation in all species after the leaching period.

The initial soluble sugars concentration was higher in alder leaves (more than $11 \%$ of dry weight) than in oak and eucalyptus leaves (around 3\% of dry weight) (Fig. 3). For all species, soluble sugars decreased dramatically during the initial decomposition stages, with no significant variations (ANOVA - litter effect) between leaf species (Table 2). The factorial ANOVA (effect time) suggests significant differences between the earlier stages (days 0, 1 and 7) and the following period (days 14, 28 and 56) $(\mathrm{F}=19.932, \mathrm{P}<0.05, \mathrm{n}=24)$.

Total polyphenol content in day 0 was higher in eucalyptus, followed by alder and oak (Fig. 4). However, after day 1, phenol concentration decreased faster in alder whilst remaining almost constant in the other two species. Oak leaves had a higher protein precipitation capacity (Fig. 5) than alder and eucalyptus leaves. However, the dynamics differ among the three species: in alder, after day 1 no precipitating activity was observed, in contrast with oak and eucalyptus. In these species, after day 7 , the protein precipitation capacity still remained high (around $0.5 \%$ tannic acid equivalents for eucalyptus and almost $1 \%$ in oak).

Table 2. Factorial ANOVA analysis (litter effect) for microbial, protein precipitation capacity (PPC), polyphenols and soluble sugars contents. The cases where no significant differences were found appear underline. $\mathrm{A}=$ alder, $\mathrm{E}=$ eucalyptus and $\mathrm{O}=\mathrm{oak}$.

\begin{tabular}{lrcc}
\hline Parameter & F-value & P-value & \\
\hline Bacteria & 6.450 & 0.0048 & EO $<$ A \\
Total Heterotrophic & 3.852 & 0.0328 & EO $<$ A \\
Yeast & 35.556 & $<0.0001$ & A $<$ E $<$ O \\
Soluble Sugars & 0.992 & 0.3778 & AEO \\
PPC & 6.514 & 0.0030 & A $<$ EO \\
Polyphenols & 4.211 & 0.0230 & A $<$ EO \\
\hline
\end{tabular}




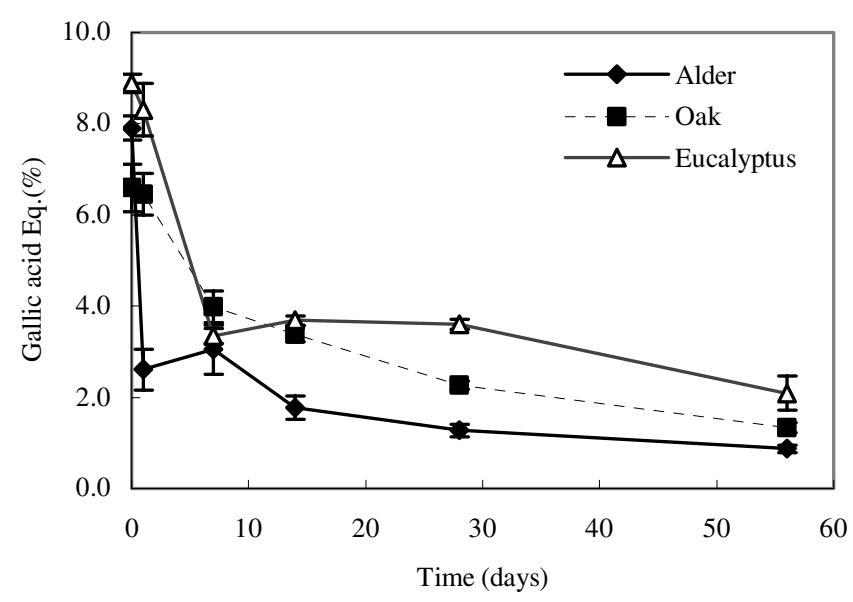

Figure 4. Temporal dynamics of total polyphenols, using gallic acid as the standard, in alder, oak and eucalyptus leaves (mean $\pm \mathrm{SD}, \mathrm{n}=4$ ).

Significative differences (Table 2) were detected between alder and eucalyptus and between alder and oak in total polyphenols and protein precipitation capacity. In both parameters no significant differences were found between oak and eucalyptus. The soluble sugars also show statistical differences $(\mathrm{P}<0.001)$ between the earlier decomposition stages (days 0,1 and 7) and the later ones (days 14, 28 and 56). The polyphenols variation exhibited a specific pattern, with significant differences between periods, except for days 7 , 14 and 28. It could seem that the release of phenols takes place between days $0-7$ (due to leaching) and after day 28 (possibly because of microbial degradation).

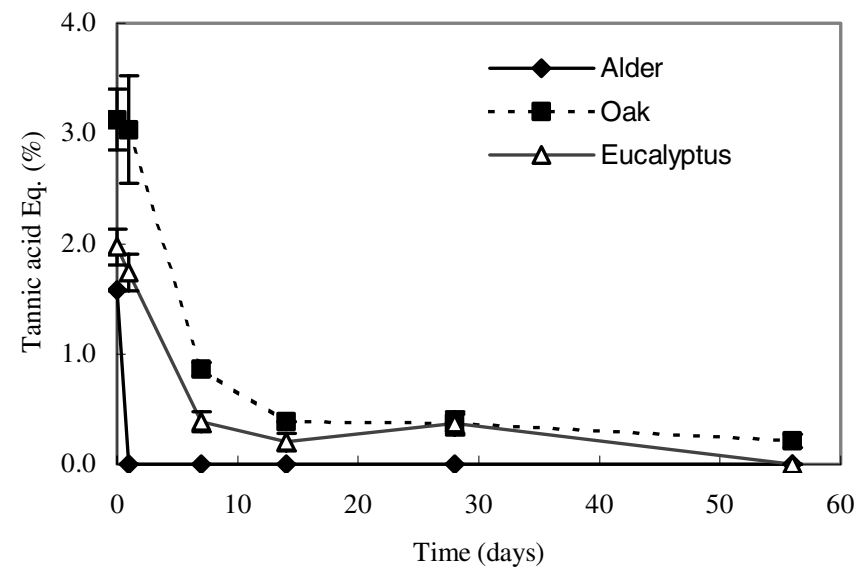

Figure 5. Temporal dynamics of protein-precipitation capacity of tannins, expressed in tannic acid equivalents, in alder, oak and eucalyptus leaves (mean $\pm \mathrm{SD}, \mathrm{n}=4$ ). 


\subsection{Microbial Colonisation}

Bacteria numbers per dry foliar mass remained almost constant in oak throughout all the experiment (Fig. 6a), whereas in alder, they increased between days 14 and 28; bacteria CFU increase uniformly in eucalyptus throughout the experiment. When total heterotrophic abundance is considered (Fig. 6b), there was only a slight increase in the middle stages for the three species. Yeast colonisation for alder exhibited a wider fluctuation when compared to the other species (Fig. 6c), where more colonies appeared at day 14. Yeast statistical differences (Table 2) occur between all studied leaf species. In the three litter species significant differences in bacteria and total heterotrophic colonisation were found between alder and the other leaves (Table 2).
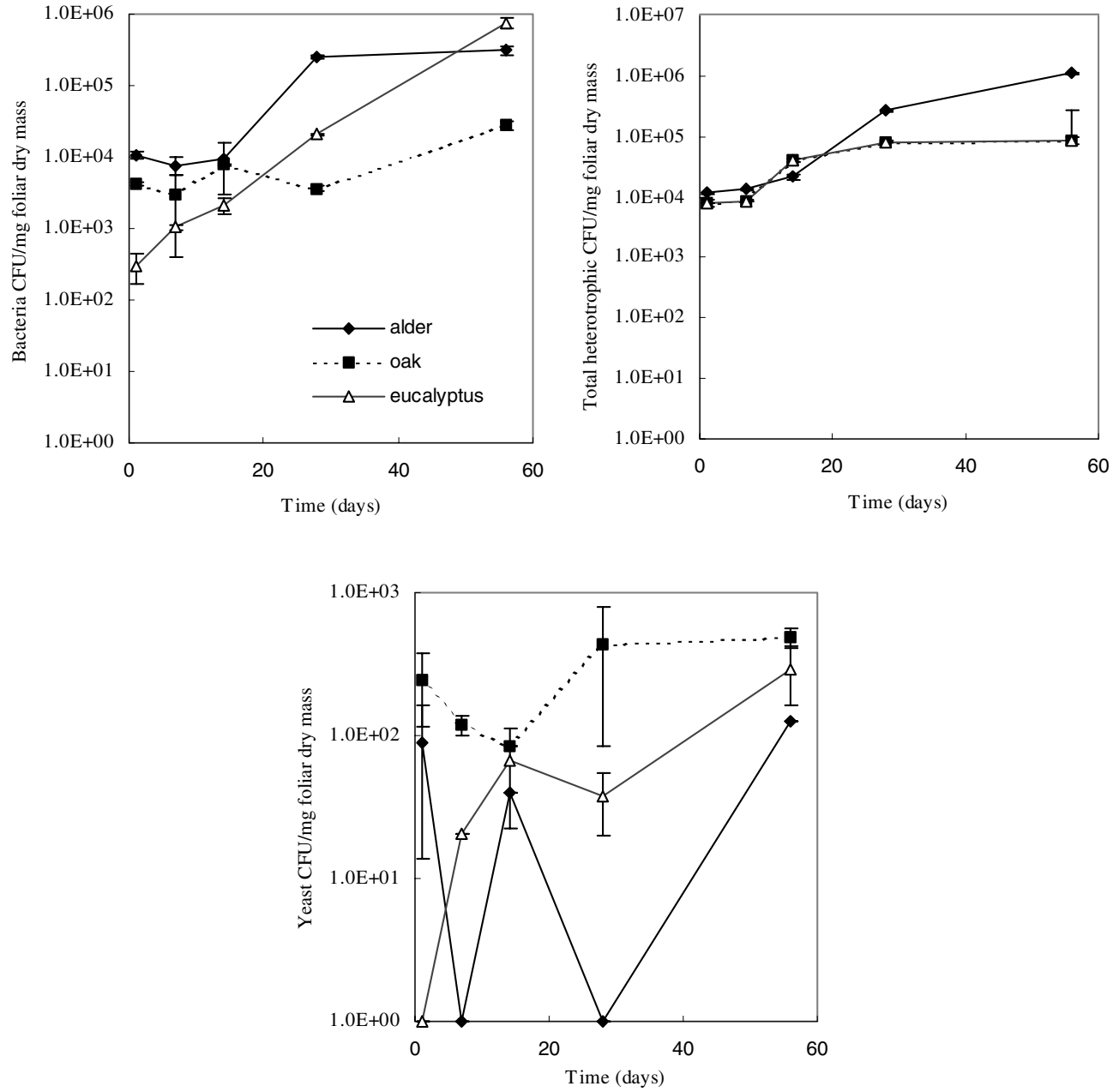

Figure 6. Temporal dynamics of microorganisms, expressed in colony forming units (CFU) per dry weight, in alder, oak and eucalyptus leaves on a semi-logarithmic scale (mean $\pm \mathrm{SD}, \mathrm{n}=3$ ). 
- Alder $\square$ Oak $\square$ Eucalyptus

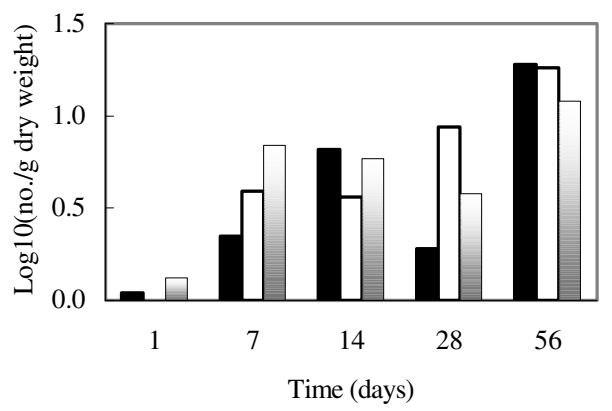

Alder DOak QEucalyptus

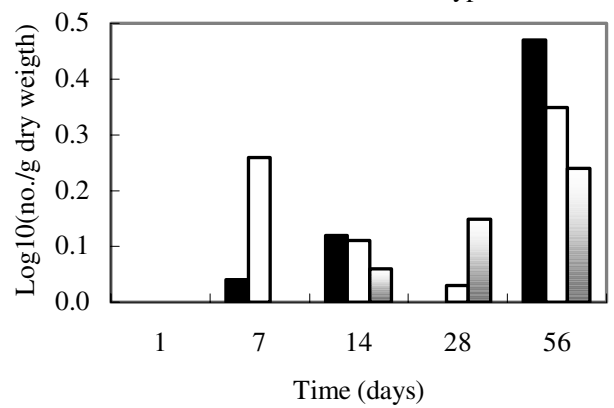

Figure 7. Total number $\left(\log _{10}\right)$ of invertebrates (left) and only of shredders (right) collected in the litterbags along decomposition.

\subsection{Macroinvertebrates}

It was not possible to detect clear differences among leaves in terms of invertebrate colonisation (Fig. 7).

DCA revealed that distinct assemblages use alder leaves when compared to both oak and eucalyptus leaves (Fig. 8). For example, despite the fact that Baetis rhodani, Hydropsyche siltilai and Simulium sp. are common to both leaf species, they are virtually absent from

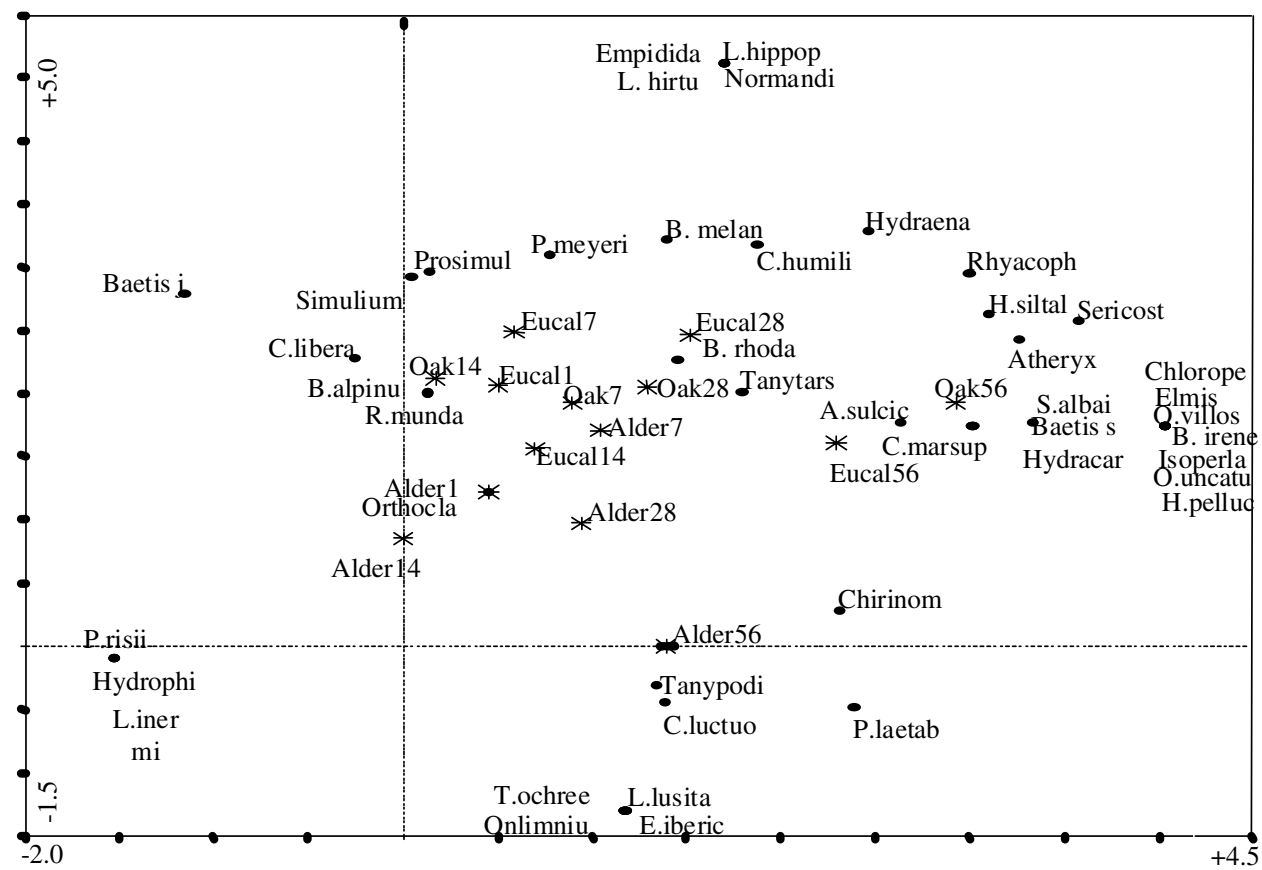

Figure 8. Diagram of DCA ordination of invertebrate species colonising leaf bags: e.g. Eucal = eucalyptus the number after the leaf indicates the sampling period. 


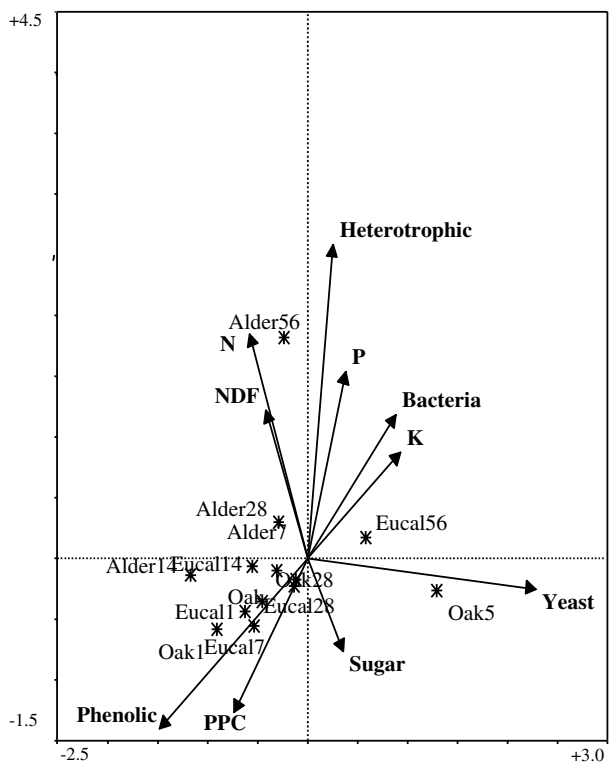

Figure 9. Diagram of CCA ordination of leaf samples. Vectors represent the variables associate to leaf composition (nutrients and microbial content). E.g. Eucal = eucalyptus, the number after the leaf indicates the sampling period. PPC = protein precipitation capacity. See explanation in the text.

alder. On the contrary, however, mayflies such as Caenis luctuosa, Eurylophella iberica and caddisflies like Leptocereus lusitanicum and Triaenodes ochreellus exhibit a preference for alder leaves. Such a preference cannot be linked to a diet related to a specific structure or higher nitrogen values, because, except for the last two invertebrate species that are detritivores, all the others are filter-feeders or deposit collectors.

A temporal gradient could be extracted from DCA ordination, indicating distinct invertebrate communities between the first stages of incubation (days 1,7 and 14) and the latter stages (days 28 and 56). Shredders like Capnioneura libera and Protonemeura meyeri were typically present for the first period and were later replaced by a community dominated by opportunistic individuals (non-shredders).

The first two axes of CCA (Fig. 9) showed a similar explanation of the total variance: $23.8 \%$ for the first and $20.8 \%$ for the second. Using the Monte Carlo permutation test, the first axis is significant $(\mathrm{P}<0.01)$, but the test, when applied to all canonical axes was not significant $(\mathrm{P}>0.05)$, reflecting a lack of correlation between species and environmental data. Figure 9 show that the most important parameters describing litter quality are related to the abundance of microorganisms, namely yeast and total heterotrophic colonies that are correlated to the $1^{\text {st }}$ and the $2^{\text {nd }}$ axes. Nitrogen and phenolic content also play a meaningful role, both variables being inverse related. Some multicollinearity could be detected as the variance inflation factors (VIFs) of these variables exceeded 20.0 (TER BRAAK, 1986). Because microbial content increases with time, whereas polyphenols and tannins decrease during the same period (particularly in the first days), samples relating to day 56 of the three leaf species appear clearly separated. A better separation between incubation periods is achieved after we selected the most representative variables (Fig.10).

An interesting observation about the invertebrates colonising leaves in this last period is the high proportion of predators, an aspect that could also be deduced from DCA analysis. On the other hand, the first stages of incubation exhibit a high number of gathers (Baetidae, 


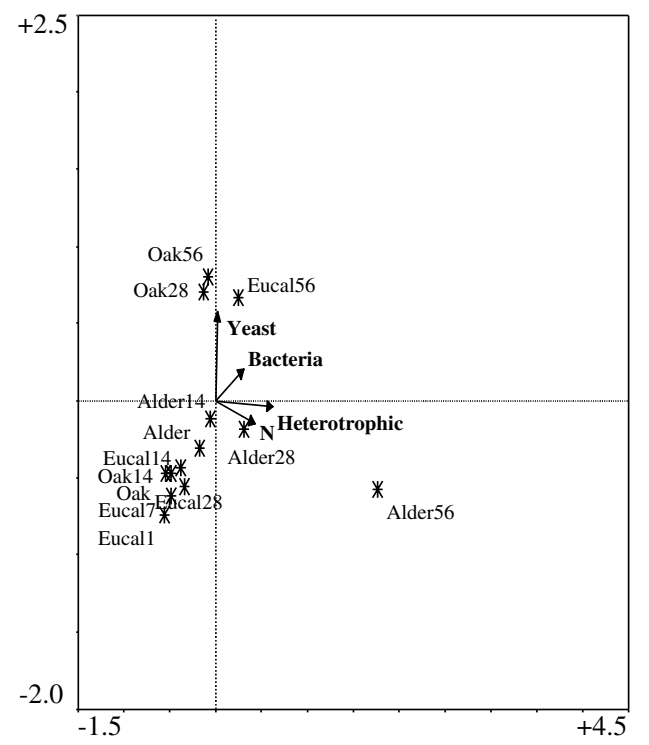

Figure 10. Diagram of CCA ordination of leaf samples, after a forward selection of the most representative variables. E.g. Eucal = eucalyptus, the number after the leaf indicates the sampling period. See explanation in the text.

Caenidae) and filters (Simuliidae), which are climbers and sprawlers (according to the classification of MERRIT and Cummins, 1984), and which can move over the leaf surface and use the FPOM accumulated thereon.

\section{Discussion}

It is known that leaves of different tree species loose mass at different rates (WEBSTER and BENFIELD, 1986) and that based on their nutritional quality it is possible to predict breakdown variation. Alder had higher $\mathrm{N}$ and $\mathrm{P}$ values (thus it is not surprising to observe comparably higher decomposition rates $\left.-0.0130 \mathrm{~d}^{-1}\right)$, followed by oak $\left(-0.0084 \mathrm{~d}^{-1}\right)$ and eucalyptus $\left(-0.0083 \mathrm{~d}^{-1}\right)$. These values are similar to those referred to by OLIVEIRA (1996) for the same stream $\left(-0.0153 \mathrm{~d}^{-1}\right.$ for alder and $-0.0088 \mathrm{~d}^{-1}$ for oak). However, higher K-values were observed for alder by GESSNER and CHAUveT (1994) $\left(0.0287 \mathrm{~d}^{-1}\right)$ and by Pozo et al., (1998) $\left(-0.0235 \mathrm{~d}^{-1}\right.$ to $\left.-0.0321 \mathrm{~d}^{-1}\right)$, which may be explained by different procedures related to timing of the study. This experiment started two months later than that of the previous authors.

The increase of nutrients during leaf incubation is considered to be due to microbial colonisation and/or nutrient immobilisation (especially where the water has a higher nitrogen content). In general, nitrogen concentration increases during leaf decay (CHAUVET, 1987; BunN, 1988a). In the present study we observed such patterns in all leaf species. Phosphorus had a more specific variation: we detected a slight decrease in alder and an increase in oak and in eucalyptus. An increase in P concentration during decay has also been described by MOLINERO et al. (1996), but these authors noticed higher $\mathrm{N}$ and $\mathrm{P}$ contents in oak relative to eucalyptus. Our results suggest that breakdown in eucalyptus is especially dependent on phosphorus, while in alder decomposition seems to be limited by nitrogen. The ratio of these two nutrients may even affect microbial colonisation: bacteria are more important in euca- 
lyptus and in oak than in alder leaves. Here, heterotrophic organisms (fungi included) appear to be more important.

Phenolics and tannins however are implicated in decay in two ways: inhibition of microbial growth and defence against herbivores, especially related to condensed tannins (DoNNELLY, 1954). Although no correlation was previously found between tannins and either leaf processing rates or microbial colonisation in streams (OSTROFSKY, 1993), we found a significant negative correlation between microbial colonisation and protein precipitation capacity $\left(r^{2}=0.516, P<0.0001, n=54\right)$ and between microbial colonisation and phenols $\left(r^{2}=0.61\right.$, $\mathrm{P}<0.0001, \mathrm{n}=54)$. The inhibitory influence of these substances may explain the increase of microorganisms (except yeast) in alder leaves after day 14, compared to oak and to eucalyptus leaves. Pozo (1993), BÄRLOCHER et al. (1995) and CHAUVET et al. (1997) also noticed a two weeks delay between alder and eucalyptus microbial colonisation. Protein precipitation capacity also disappeared more rapidly from alder (after day 1 no proteinprecipitating activity was detectable) than from the other two litter species. This is probably because alder has thinner leaves and has no cuticular waxes or oils when compared to oak and eucalyptus. BÄrLOCHER et al. (1995), obtained a faster decline of phenolics and tannins after having previously extracted the lipids from eucalyptus leaves. Determining what types of tannins are lost could provide another explanation: hydrolysable tannins (simple molecules) or condensed tannins (polymers of catechin and/or epicatechin). The ratio between these two types varies with plant species (GARRO et al., 1997).

The relative importance of microorganisms in leaf litter breakdown has been widely discussed and it is generally accepted that in both small streams and large river microorganisms play an important role. The fungi are recognised as the first colonisers (SUBERKROPP and KLUG, 1976; SuBERKROPP, 1991; GESSNER and CHAUVET, 1994; BALDY et al., 1995), followed by bacteria, whose contribution increases at advanced stages of decomposition. The fungi capacity to degrade the plant cell wall is associated to its morphology (a filamentous structure that penetrates deeply into leaf tissue). The ability to attach to surfaces also gives them a competitive advantage. Within an aerobic environment fungi also have an enzymatic advantage: only a few aerobic bacteria seem able to degrade crystalline cellulose or other cell-wall polymers (BHAT et al., 1993). It has been proposed that fungi and bacteria compete with each other for nutrients (SuberkropP and Klug, 1976; ChAMIER et al., 1984), but BENGTSSON (1992) did not find any competitive inhibition and also proposed that such a relation was synergistic.

Authors who have used simultaneously mesh bags and plastic leaf traps, like DoBson (1991) and GRAÇA and PEREIRA (1995), claimed also that leaf packs are as often used as shelter rather than as a food source, especially in situations of extreme discharges. For instance, in the latter work, shredders were no more abundant in natural leaves when compared to plastic strips. That could be as a consequence of harsh situations, masking the potential dissimilarities in faunistic composition between leaf species (CORTES et al., 1997). Of course that the alteration of the invertebrate community (e.g. shredder diminution due to insecticide application in stream) influence leaf litter processing rates (reduction of $50-74 \%)$ as recorded by CUFFNEY et al. (1990), which proved that this biota play as well an important role in decomposition.

Total heterotrophic CFUs for alder leaves seem more relevant when compared to the other two leaf species. Bacteria possibly play a role in eucalyptus and oak leaves (illustrated by CCA ordination) especially at advanced decomposition stages. All the studies that try to understand the role of microorganisms in leaf litter processing are about bacteria and/or filamentous fungi, because both groups are recognised involved in organic matter degradation. Our study included another kind of fungi: yeasts. These microorganisms have been always considered incapable of degradation of the principal constituents of plants. However, there are several references that refutes this idea. Cellulose degradation by yeasts was notice by DENNIS (1972) in Trichosporon and in Aurediobasidium by FlannIGAN (1970). Xilanase activities were also found in Aurediobasidium, Cryptococcus, Trichosporon (BIELY et al., 1978) and in Candida 
and Filobasidium (JIMENÉZ, 1991). In spite of no ligninolytic enzymes have been described in yeasts (JIMENÉZ, 1991), some of them are capable of metabolising low molecular weight aromatic compounds related to this polymer (MIDDELHOVEN, 1993 and SAMPAIO, 1999).

Yeast and yeast-like fungi increase their number later in the decaying process and presumably are opportunistic organisms interested on easier to assimilate substances released during degradation by other fungi and/or bacteria. However, this group differs significantly between leaf species and is strongly correlated with soluble sugars (positively) and with phenols (negatively). We did not found any references in the literature, to the causes of yeast variation along leaf breakdown in aquatic systems. The unstable pattern in yeast colonisation (especially in alder leaves) may reflect variations on the substrate type availability to which they are very sensitive during incubation. Further experiments are needed to shed some light on the temporal succession of these organisms.

Shredder density was generally higher in alder than in oak and eucalyptus leaves. In this study we observed that Nemouridae and Leuctridae preferentially colonised alder and that Simuliidae only appeared in oak and eucalyptus leaves. BASAGUREN and Pozo (1994) also pointed out that Simuliidae was the most abundant group (47\%) in eucalyptus leaves, whereas Nemouridae preferred alder leaves. This may be due to the fact that Simmuliidae need a substrate to attach on, and eucalyptus leaves are more robust than the thinner and easier degradable alder leaves. We also observed that shredders (where Leuctridae and Nemouridae were the dominant families), increase their density after the initial leaching of phenolics. This happens not only because these substances may retard microbial growth (BunN, 1986, 1988b), but also because they directly impact on macroinvertebrates. Some of these observations became even more evident when a forward selection of the variables expressing litter quality and microbial colonisation is made (Fig. 10), allowing a more distinct separation between incubation periods. From these variables this procedure selected successively heterotrophic, yeast and bacteria densities, and $\mathrm{N}$ content, representing nearly $60 \%$ of the variance of all variables, however only the first two axe are significant $(\mathrm{P}<0.05)$.

The evidence of specific preferences of some invertebrates, in spite of the opportunistic character of most of the colonising species that are food generalists (KING et al., 1987), has already been pointed out for poor headwaters streams (CORTES et al., 1994; CANHOTO and GRAÇA, 1995). These authors suggest, therefore, that the replacement of native riparian vegetation by eucalyptus may led to significant ecological implications in the food web, even if this impact may be more reduced in streams with high P levels (Pozo et al., 1998). However, CHAUvet et al. (1997) showed that eucalyptus leaves support a fungal community roughly comparable with that observed on the alder leaves, but that the aquatic hyphomycetes colonisation is delayed for about two weeks, because the material is more refractory.

The most relevant aspect of invertebrate species succession in leaf bags during colonisation are related to specific assemblages for alder litter, compared to oak and eucalyptus. As mentioned previously, invertebrate colonisation may not be linked to leaf composition, therefore we must be cautious about the role of specific parameters.

\section{Acknowledgements}

We thank to Fernando Ferreira for field work assistance and to Prof. Chris Gary for the English correction of the manuscript. This study was partially supported by PRAXIS 2130/95 project.

\section{References}

Abelho, M. and M. A. S., GraÇA, 1996: Effects of eucalyptus afforestation on leaf litter dynamics and macroinvertebrate community structure of streams in Central Portugal. - Hydrobiologia 324: 195-204. 
ANDERSON, N. H. and J. R., Sedell, 1979: Detritus processing by macroinvertebrates in stream ecosystems. - Ann. Rev. Entomology 24: 351-377.

Ashwell, G., 1957: Colorimetric analysis of sugars. - Meth. Enzymol. 3: 73-105.

Baldy, V., M. O. Gessner and E. Chauvet, 1995: Bacteria, Fungi and the breakdown of leaf litter in a large river. - Oikos 74: 93-102.

BÄrlocher, F., C. CANHoto and M. A. S. GraÇA, 1995: Fungal colonization of alder and eucalyptus leaves in two streams in Central Portugal. - Arch. Hydrobiol. 133: 457-470.

Basuguren, A. and J. Pozo, 1994: Leaf litter processing of alder and eucalyptus in the Agüera stream system (Northern Spain). II. Macroinvertebrates associated.- Arch. Hydrobiol. 132: 57-68.

Bengtsson, G., 1992: Interactions between fungi, bacteria and beech leaves in a stream microcosm.Oecologia 89: 542-549.

Bhat, S., P. W. Goodenough, E. Owen and M. K. Bhat, 1993: Cellobiose: A true inducer of cellulosome in different strains of Clostridium thermocellum. - FEMS Microbiol. Letters 111: 73-78.

Biely, P., Z. KrátKy, A. Kocková-KRAtochvílovÁ and S. BAUER, 1978: Xylan-degrading activity in yeasts: growth on xylose, xylan and hemicellulose. - Folia. Microbiologica. 23: 366-371.

BunN, S. E., 1986: Origin and fate of inorganic matter in Australian upland streams. - In: DEKKER, P. and Williams, W. D., (eds.) Limnology in Australia. Junk Dordrecht, 227-291.

BunN, S. E., 1988a: Processing of leaf litter in two northern jarrah forest streams: Western Australia: I. Seasonal differences. - Hydrobiologia 162: 201-210.

BunN, S. E., 1988b: Processing of leaf litter in two northern jarrah forest streams: Western Australia: II. The role of macroinvertebrates and the influence of soluble polyphenols and inorganic sediment. - Hydrobiologia 162: 211-223.

CAnhoto, C. and M. A. S. GraÇA, 1995: Food value of introduced eucalypt leaves for a Mediterranean stream detritivore: Tipula lateralis. - Freshwat. Biol. 34: 209-214.

CAnнoto, C. and M. A. S. GraçA, 1999: Leaf barriers to fungal colonization and shredders (Tipula lateralis) consumption of decomposing Eucalyptus globulus. - Microbial Ecology 37: 163-172.

Chamier, A. C., P. A. Dixon and S. A. ArCHER, 1984: The spatial distribution of fungi on decomposing alder leaves in a fresh water stream. - Oecologia 64: 92-103.

Chamier, A. C., 1987: Effect of $\mathrm{pH}$ on microbial degradation of leaf litter in seven streams of the English Lake District. - Oecologia 71: 491-500.

Chauvet, E., 1987: Changes in the chemical composition of alder, poplar and willow leaves during decomposition in a river. - Hydrobiologia 148: 35-44.

Chauvet, E., E. FABre and A. Elósegui, 1997: The impact of eucalypt on the leaf-associated aquatic hyphomycetes in Spanish streams. - Can. J. Bot. 75: 880-887.

Cortes, R. M. V., M. A. S. GraÇA and A. Monzón, 1994: Replacement of alder by eucalypt along two streams with different characteristics: Differences on decay rates and consequences to the system functioning. - Verh. Internat. Verein. Limnol. 25: 1697-1702.

Cortes, R. M. V., M. A. S. GraçA, J. N. Vingada and S. V. Oliveira, 1995: Stream typology and dynamics of leaf processing. - Annls Limnol. 31: 119-131.

Cortes, R. M. V., M. AbeLho and S. B. Rebelo, 1997: The macroinvertebrate colonization of leaf bags: is there a pattern? - Limnética 13: 71-75.

CuffNey, T. F., J. B. WAllace and G. J. Lugthart, 1990: Experimental evidence quantifying the role of benthic invertebrates in organic matter dynamics of headwater streams. - Freshwat. Biol. 23: 281-299.

DENNIS, C.,1972: Breakdown of cellulose by yeast. - J. Gen. Microbiol. 71: 409-411.

Dobson, M., 1991: An assessment of mesh bags and plastic leaf traps as tools for studying macroinvertebrate assemblages in natural leaf packs. - Hydrobiologia 222: 19-28.

DonNelly, E. D., 1954: Some facts that affect palatability in scricca lespedeza L. cuneata. - Agron. J. 46: $96-97$.

FlanNigan, B., 1970: Degradation of arabinoxylan and carboxymethyl cellulose by fungi isolated from barley kernels.. - Transactions of the British Mycol. Soc. 55: 277-281.

Garro, J. M. G., B. Riedel and A. H. ConNer, 1997: Analytical studies on tara tannins. - Holzforschung 51: $235-243$.

GeSSNER, M. O. and E. CHAUvET, 1994: Importance of stream microfungi in controlling breakdown rates of leaf litter. - Ecology 75: 1807-1817.

GraÇA, M. A. S. and A. P. Pereira, 1995: The degradation of pine needles in a Mediterranean stream. - Arch. Hydrobiol. 134: 119-128. 
Hagerman, A. E., 1987: Radial diffusion method for determining tannin in plant extracts. - J. Chem. Ecol. 13: 437-445.

HILL, M. O., 1979: Decorana a Fortrand program for detrended correnpondence analysis and reciprocal averaging. Cornell University, Ithaca, New York, USA.

Jiménez, M., A. E. GonZÁlez, M. J. Martínez and A. T. Martínez, 1991: Screening of yeasts isolated from decayed wood for lignocellulose-degrading enzyme activities. - Mycol. Res. 95: 1299-1302.

King, H. G. C., M. P. Henshall-Howard, J. A. Day and B. R. Davies, 1987: Leaf-pack dynamics in a southern african mountain stream. - Freshwat. Biol. 18: 325-340.

Melillo, J. M., R. J. Naiman, J. D. Aber and A. E. Linkins, 1984: Factors controlling mass loss and nitrogen dynamics of plant litter decaying in northern streams. - Bull. Mar. Sci. 35: 341-356.

Merrit, R. W. and K.W. Cummins, 1984: An introduction to aquatic insects of North America. $2^{\text {nd }}$ ed. (eds.) Kendall/Hunt, Dubuque, USA.

MidDelhoven, W. J., 1993: Catabolism of benzene compounds by ascomycetous and basidiomycetous yeasts and yeast-like fungi: a literature review and an experimental approach. - Antonie van Leeuwenhoek 63: 125-144.

MilLs, H. A. and J. B. JonES, JR., 1996: Plant analysis handbook II. MicroMacro Publishing Inc. Georgia. U.S. A.

Minshall, G. W., 1967: Role of allochtonous detritus in the trophic structure of a woodland springbrook community. - Ecology 48: 139-149.

Molinero, J., J. Pozo and E. GonZAlez, 1996: Litter breakdown in streams of the Agüera catchment: influence of dissolved nutrients and land use. - Freshwat. Biol. 36: 745-756.

NovozAMSKI, I., V. HouBA, R. VAN ECK and VAN WARK, 1983: A novel digestion technique for multielement plant analysis. - Communications in Soil Science and Plant Analysis 14: 239-249.

OliveirA, S. V., 1996: Importância das ripícolas no funcionamento dos ecossistemas lóticos: caso do rio Olo (P. N. Alvão). Dissertação de mestrado. U.T.A. D. Portugal.

OSTROFSKY, M. L., 1993: Effect of tannins on leaf processing and conditioning rates in aquatic ecosystems: an ecological approach. - Can. J. Fish. Aquat. Sci. 50: 1176-1180.

Petersen, R. C. and K. W. Cummings, 1974: Leaf processing in a woodland stream. - Freshwat. Biol. 4: 343-368.

Pozo, J., 1993: Leaf litter processing of alder and eucalyptus the Agüera stream system (North Spain). I. Chemical changes. - Arch. Hydrobiol. 127: 299-317.

Pozo J., A. Basaguren, A. Elósegui, J. Molinero, E. Fabre and E. Chauvet, 1998: Afflorestation with Eucalyptus globulus and leaf litter decomposition in streams of northern Spain. - Hydrobiologia 373/374: 101-110.

Roberteson, J. B. and P. J. van SoEst, 1981: The detergent system of analysis and its application to human foods. - In: JAMES, W. P. T. and THEANDER, O., (eds.) The Analysis of Dietary Fiber in Food., $123-158$.

Rosset, J., F., BÄrLocher, and J. J. Oertli, 1982: Decomposition of conifer needles and leaf litter in two Black Forest and two Swiss Jura streams. - Int. Rev. ges. Hydrobiol. 67: 695-711.

SAMPAIO, J. P., 1999: Utilization of low molecular weight aromatic compounds by heterobasidiomycetous yeasts: taxonomic implications. - Can. J. Microbiol. 45: 491-512.

SubERKROPP, K. and M. J. KLUG, 1976: Fungi and bacteria associated with leaves during processing in a woodland stream. - Ecology 57: 707-719.

SUBERKROPP, K., 1991: Relationships between growth and sporulation of aquatic hyphomycetes on decomposing leaf litter. - Mycol. Res. 95: 843-850.

Ter BRAAK, C. J. F. 1986: Canonical Correspondence Analysis: a new eigenvector technique for multivariate direct gradient analysis. - Ecology 67: 1167-1179.

TER BRAAK, C. J. F., 1987: Canoco - a FORTRAND program for canonical community ordination by partial detrended canonical correspondence analysis, principal component analysis and redundancy analysis (version 2.1). DLO -Agricultural Mathematics Group, Wageningen, The Netherlands.

TER BRAAK, C. J. F. and P. SMILAUder, 1998: CANOCO reference manual and user's guide to Canoco for Windows: software for Canonical Community Ordination (version 4). Microcomputer Power, Ithaca, USA.

WebsteR, J. R. and E. F. Benfield, 1986: Vascular plant breakdown in freshwater ecosystems. - Ann. Rev. Ecol. Systematics 17: 567-594. 